\title{
Violence, Culture and Resistance: New Directions in the Study of Settler Colonialism and Indigeneity
}

\author{
Ian C. Hartman
}
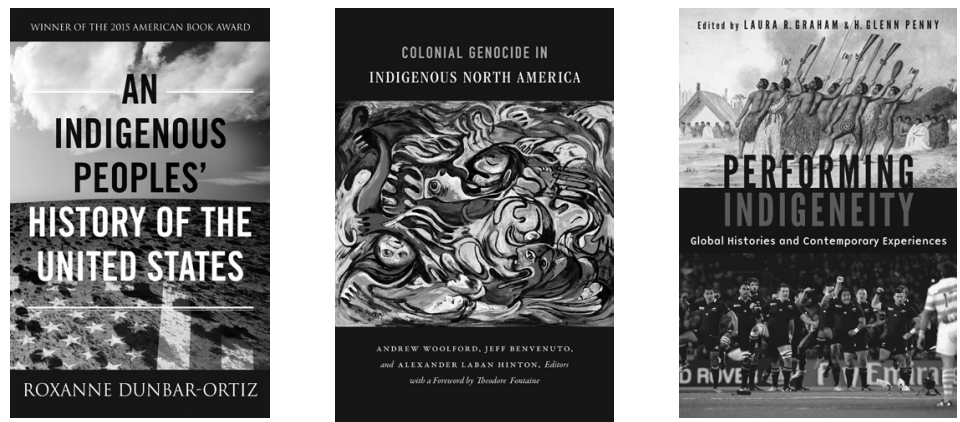

AN INDIGENOUS PEOPLES' HISTORY OF THE UNITED STATES. By Roxanne Dunbar-Ortiz. Boston, MA: Beacon Press. 2014.

COLONIAL GENOCIDE IN INDIGENOUS NORTH AMERICA. Edited by Andrew Woolford, Jeff Benvenuto, and Alexander Laban Hinton. Durham, NC: Duke University Press. 2014.

PERFORMING INDIGENEITY: Global Histories and Contemporary Experiences. Edited by Laura Graham and H. Glenn Penny. Lincoln: University of Nebraska Press. 2014. 
In her influential book Transit of Empire, Indigenous scholar Jodi Byrd has provocatively asserted, "The story of the new world is horror, the story of America is a crime." The line, to varying degrees, reflects an assumption and theme that courses through these works, two of which are edited collections and one that reenvisions North American history, putting Indigenous people at the center of the story. But if the colonization of the continent was indeed a crime, as many of the writers featured here might broadly agree, there is much disagreement over the nature of the offense. For certain, the history of settler colonialism has wrought devastation and violence, but it has also engendered resistance at every turn and, in the face of great obstacles, fostered new expressions of cultural vitality among the world's Indigenous people.

Roxanne Dunbar-Ortiz's An Indigenous History of the United States, along with Woolford, Benvenuto, and Hinton's volume, argues that the actions of some white settlers met the legal definition of genocide. ${ }^{2}$ These two books emphasize the role of violence in shaping North American history since the late 1400s. Conversely, the collection of essays edited by Laura Graham and H. Glenn Penny demonstrate the creative ways in which Indigenous people have asserted cultural and performative autonomy, both highly symbolic modes of resistance amid the systemic disruptions that millions of men and women have endured for over five centuries of colonization. Taken together, these three works represent some of the latest and strongest scholarship coming out of Indigenous studies. At their best, the authors refashion our understanding of national histories and convey how colonialism remains a process deeply embedded in our present moment.

Dunbar-Ortiz rejects the classification of her ranging book as solely a work of Indigenous history. In fact, she states firmly from the outset, "This is a history of the United States" (14). In its stronger moments, An Indigenous Peoples' History of the United States is even global in scope, offering fresh comparisons and linkages to settler colonialism in other contexts such as in Ireland, the Caribbean, and the Pacific. However, as a word of caution, this is a work of synthesis, so the reader should not expect to encounter wholly new insights or previously unknown sources. Instead, Dunbar-Ortiz mostly presents well-known and widely studied events. Still, the book challenges triumphalist accounts of US history based on the achievements of Great Men (presidents, frontier settlers, and cultural icons to name just a few). And while such top-down narratives have fallen out of favor among most academics, Dunbar-Ortiz's book will further dislodge any lingering notions of a heroic past defined by brave frontiersmen who settled the continent in the name of liberty, justice, and equality. Hers is a more complex and darker story.

An Indigenous Peoples' History first delves into the social and cultural arrangements of North America's precolonial societies. Given the scope and breadth of the book, Dunbar-Ortiz cannot describe the nuances of these early civilizations in thorough detail, but she does bust the myth that they were inferior or more simplistic to European forms of social organization. People of the Pacific Northwest, for example, developed highly organized cultures based on abundant 
salmon and timber. Meanwhile, corn and wild game nourished millions of others in the heart of the continent. One could travel from the Pacific Coast, across the Rocky Mountains, and through the Mississippi watershed to the Atlantic via an extensive network of trade and migratory routes that included rivers, streams, overland trails, and treacherous mountain passes. Dunbar-Ortiz's crash course on thousands of years of history "counteracts the settler-colonial myth of the wandering Neolithic hunter" (31).

Once Dunbar-Ortiz establishes the degree to which Indigenous people had organized their respective societies in the so-called New World, she discusses the impact that Europeans had on the people and the land. For Dunbar-Ortiz, English colonization was a brutal affair; the methods of which were seen first in Northern Ireland, then in Virginia and Massachusetts. Whether it was Pequot War in the 1630s that raged across New England or Bacon's Rebellion in the 1670s in Virginia, Dunbar-Ortiz concludes the settlers sought not only to drive Indigenous people from the land but in some cases to rid the continent of them entirely. Men like John Mason and William Bradford documented the encounters between their fellow white settlers and those who they determined were heathens. Far from heroic men worthy of high praise, Dunbar-Ortiz relates organized efforts to kill as many Indigenous men, women, and children as possible; the infamous Mystic massacre of 1637 serves as an example (62-63). The briskly paced volume moves through colonial American history into the Revolutionary War Era. Following the Seven Years War in 1763, European settlers pushed beyond the Proclamation Line and squatted on Indian land in the trans-Appalachian West. These men and women grew impatient with the English Crown as it tried to temper westward expansion and stabilize the existing trade and commerce of the east coast. This, according to Dunbar-Ortiz, perhaps more than any other single reason, led to the Revolutionary War. ${ }^{3}$

As the public figure most associated with Indian Removal, it is not surprising that Dunbar-Ortiz singles out Andrew Jackson as particularly nefarious. Jackson, sometimes regarded as a founder of the Democratic Party, prioritized land ownership and white male suffrage but did so at tremendous cost to the continent's earliest inhabitants. Here, Dunbar-Ortiz provides a smattering of familiar quotes that contemporary historians should know. Dunbar-Ortiz narrates the mid-nineteenth century swiftly — commonly referred to as the Antebellum Era—accentuating settler-Indigenous relations. Significantly, the term "antebellum"- 'before the war'-loses its meaning if we shift the perspective towards Native America and away from the sectional crisis that defines conventional interpretations of the middle of the nineteenth century. From an Indigenous point of view, there were few moments "before the war" during the 1800s. By the 1840s, people of European descent streamed across the country in search of gold, glory, and land. California was the site of extreme brutality. While Indigenous Californians faced Spanish incursions for well over a century, white Anglos operating as a US occupation force brought a "true reign of terror." Between 1850 and 1875, the Indigenous population of the Golden State plummeted from one-hundred thou- 
sand to below thirty thousand, or "quite possibly the most extreme demographic disaster of all time" (129).

Additional efforts to eliminate or marginalize Native people west of the Mississippi River continued in earnest after 1865. With the union secure, consecutive presidential administrations directed vast resources westward. Indigenous nations such as the Sioux, the Nez Perce, Apache, Cheyenne, and the Comanche, among others, resisted the US military's advance, and many Native people refused to be corralled on reservations. Thousands of men and women responded in various ways, from armed opposition and uprisings to cultural expressions of autonomy. However, the firepower, manpower, and sheer violence inflicted upon Indigenous people by the United States proved difficult to overcome. Dunbar-Ortiz conveys a familiar timeline of atrocities that occurred throughout the latter decades of the nineteenth century, but she reminds readers that Native American resistance abounded after the infamous and well-documented massacre at Wounded Knee in 1890. Still, the event marked a symbolic shift in Indigenous/settler relations. As military occupation of the West repeatedly culminated in mass slaughter, Native people were left with few options other than adopting European notions of private land ownership as prescribed in the Dawes Act (1887). And though it seemed a fait accompli among white settlers and their federal, state, and local governments that Native people would "vanish" as the twentieth century world came into view, they nevertheless persisted.

While "utter military triumph on the continent," as Dunbar-Ortiz calls it, may have been complete by the 1890s, US expansion was far from over (161). Indeed, the twentieth century witnessed a newly assertive US on the global stage, a development that became possible only with the conquest of the Indigenous population in the West. In her view, Guam, Hawai'i, Alaska, the Virgin Islands, American Samoa, the Marshall Islands, Northern Mariana, and Puerto Rico were merely extensions of an established policy rather than a new chapter in the nation's history and foreign policy. In an era known as the nadir of race relations, Indigenous people, along with African Americans, immigrants, and now colonized people in the Caribbean and Pacific, faced hostile treatment and lived under constant threat of state and vigilante violence. The brutal suppression of Filipino resistance to US American occupation illustrates one potent example of this (164-65). At the same time, the compulsory adoption of private property, the destruction of the environment, and the proliferation of Indian boarding schools all highlight a coherent policy on the part of the federal and state governments to extinguish Native culture and identity in the early twentieth century.

The New Deal brought brief abatement to some Indigenous people. Under the direction of John Collier, the Bureau of Indian Affairs (BIA) charted a new direction, moved away from its insistence on the assimilation of the Dawes Act, and advocated more autonomy for Indigenous people. For the first time, assimilationist policies long advocated by the federal government took a backseat to cultural and political preservation. But amid fears of communism, the Truman and Eisenhower administrations rolled back Collier's BIA policies and once 
again stressed assimilation in white society. The post-World War II approach, known as termination, sought to extinguish collective land holdings and independent tribal governance, pillars of the so-called Indian New Deal of the 1930s and 1940s. Termination incentivized Indigenous people to leave their ancestral homelands for the city. By the 1960s, San Francisco, Los Angeles, New York, Minneapolis, Seattle, and Chicago all developed sizable Native communities. In these urban spaces, a younger generation of Native women and men forged a pan-Indian identity, perhaps only possible within the diverse, multicultural setting of the modern city. Though it was an unintended consequence of the Cold War termination policy, the migration of Indigenous people to urban areas provided the immediate context and one of the precipitating causes of the American Indian Movement (AIM).

Connecting the American Indian Movement to other prominent social movements, Dunbar-Ortiz shows how AIM fought for self-determination and the ability to make decisions free from the influences of white-led governments. Movement leaders reclaimed their history and cultivated autonomous institutions. Other notable victories included the establishment of Native American Studies programs in several public and private universities, a proliferation of Indigenous history and culture, increased access to healthcare and education, and greater sovereignty. While the social movements of the 1960s and 1970s represented a high watermark in Indian activism, Dunbar-Ortiz quickly points out that colonialism has continued into the present. Indian country today still has some of the highest poverty and unemployment rates in the nation and suffers from federal neglect and institutional racism.

But if the United States has failed its Indigenous communities, one might look to how the nation has stewarded its vast resources elsewhere. Trillions of dollars have supported invasions across the Middle East and paid for the so-called Global War on Terror. These conflicts have provided the US military with a seemingly permanent footprint abroad even as poverty and inequality have increased domestically. The march to war has also led to the wave of crackdowns on dissent. Yet, Dunbar-Ortiz reminds us that the posture of the US military since 9/11 does not represent a total break with the past. Indeed, with over nine-hundred military installations and a presence on every continent, the United States has maintained an imperial reach for decades. The current military positioning reveals the nation's continued reliance on the world's natural resources and access to stable markets and cheap labor. Just as the military led violent incursions into Indian country to shore up corporate interests in the energy and mining sectors, so too has the military been deployed in the deserts and oceans thousands of miles away for similar purposes.

Accordingly, the anti-war and anti-racist struggle must be situated in a history of anti-colonial resistance; here the significance of Indigenous histories becomes paramount. In sum, Dunbar-Ortiz proposes that the United States has acted as an aggressive, expansionist power since its incipience; she makes the case quite effectively. As two settler states, it is no longer excusable to accept 
the celebratory paeans that too often pervade the national histories of the United States and Canada. Of course many students and scholars will find much of what Dunbar-Ortiz has written familiar and not terribly groundbreaking. As mentioned, this is not a work of original scholarship, nor does it profess to be. Rather, the book brings together the latest historiography of Indigenous/settler relations and weaves a cohesive and unapologetic account of US American history.

Undoubtedly, An Indigenous Peoples' History of the United States strikes a strident tone, and some will dismiss the work as too polemical. But books like these are intended to challenge the nation's values and assumptions and foster spirited dialogue. For certain, militarism, capitalism, and nationalism are ideological currents that run deep and will continue to receive uncritical acceptance and celebration in many quarters. Still, uncovering the past from Indigenous points of view and fully reckoning the implications and legacies of a nation built on land expropriation and cultural destruction might one day yield a more equal and compassionate society, one that measures strength not in dollars and cents or in the size of the military but on respect for difference, history, and pluralism.

Dunbar-Ortiz's book also serves as a primer for deeper explorations of Indigenous history and culture. Thus, if An Indigenous Peoples' History could be analogous to a survey text on the topic, Andrew Woolford, Jeff Benvenuto, and Alexander Laban Hinton's edition, Colonial Genocide in Indigenous North America and Laura Graham and H. Glenn Penny's collection of essays in Performing Indigeneity provide the latest in the discipline and are pitched at more specialized audiences. The contributing authors in Colonial Genocide in Indigenous North America have limited themselves to a specific, but profound issue: genocide. Too often the term is bandied about without precision. For this reason, Woolford, Benvenuto, and Laban Hinton suggest that scholars of Indigenous history adhere to the definition of the term provided by the 1948 United Nations Convention on the Prevention and Punishment of the Crime of Genocide. This convention codified genocide as

Acts committed with intent to destroy, in whole or in part, a national, ethnic, racial or religious group, as such, including the following: A. Killing members of the group; B. Causing serious bodily or mental harm to members of the group; $\mathrm{C}$. Deliberately inflicting on the group conditions of life calculated to bring about its physical destruction in whole or in part; D. Imposing measures intended to prevent births within the group; E. Forcibly transferring children of the group to another group (2).

The violence inflicted on the continent's first inhabitants through centuries of colonialism has fostered a plethora of outcomes. Some of these events clearly constituted genocide; others did not. Hence, the contributors explore the consequences of settler colonialism under a rubric of five themes: identity, resistance, loss, intersectionality, and transformations. The contributors know how incendiary charges of genocide are and exactly what the word conjures in 
the public mind. But rather than inviting the readers to get caught up with the word itself, we are told "the concept of genocide offers an analytical device for evaluating destructive relations of domination and subordination so that such relations might be changed and ongoing patterns of colonial genocide in North America brought to halt" (13).

The authors come from backgrounds that include genocide studies, anthropology, history, public policy, and community activism. Robbie Ethridge's "Global Capital, Violence, and the Making of a Colonial Shatter Zone" is an especially useful and historically focused essay. Ethridge defines a "shatter zone" as the space Indigenous communities navigated as they encountered the "inauguration of the nascent capitalist economic system" (49). A combination of violence, pathogens, and commercial trade resulted in the collapse of what Ethridge calls the Mississippian world. Because colonialism took highly disparate forms over the two hundred years preceding the American Revolution, Ethridge believes that genocide does not neatly fit the experience of most Indigenous societies east of the Rockies. But regardless of what one may term the ordeal, Ethridge certainly locates the role of violence and slaving as central to the rise of global capitalism and the destruction of an entire civilization between the 1500s and 1700s. Jeff Benvenuto's essay examines "Choctaw ethnocide" and dialogues directly with Ethridge's intervention. According to Benvenuto, "Choctaw enthnogenesis picked up some of the shattered pieces of the Mississippian shatter zone" (215). The brief essay acknowledges the destruction of Choctaw society but does not overlook the "resistance, survival, and regeneration" of the Choctaw people and their culture in the Native South (217). Genocide and ethnocide, while accurately categorizing the actions of some settlers, should not be the only, or even the primary, lens through which to view a complex set of interactions, Benvenuto clarifies.

On the other hand, Christopher Powell and Julia Peristerakis, along with Margaret D. Jacobs, Jeremy Patzer, and David MacDonald, have focused on the residential schools in Canada. These authors believe that genocide is indeed an apt way to describe the policies of the Canadian government, particularly during the second half of the nineteenth century and well into the twentieth. During these decades, the residential schools eliminated the culture, language, and identities of First Nations people. Patzer proposes that the schools had "genocidal institutional arrangements" and "represent, par excellence, the disempowerment, dispossession, and loss of self-determination of a people" (182). Jacobs writes about child removal and concludes that the practice constituted a "habit of elimination" carried out at the highest levels of governance. Likewise, Powell and Peristerakis argue, "specific measures or practices or forms of action that would not be genocidal on their own may combine with other processes, undertaken by other agents and for unrelated motives to form a genocidal process" (75). Phrases like "genocidal process," "genocidal institutional arrangements," and "habits of elimination" thus best sum up the variegated policies of Canada's government towards Indigenous people during much of the twentieth century. 
And critically, though Canada may not have directed the same level of military firepower towards Native people that the United States did, the northern nation willfully enacted policies that contributed towards the collapse of Indigenous societies. The residential school system is a prime and lamentable example.

Benjamin Madley and Gray H. Whaley explore the tumultuous colonization of northern California and southern Oregon between 1850 and 1873. As Madley demonstrates, the Modocs were not passive recipients of white aggression, but they nevertheless faced a genocidal program carried out by the newly admitted State of California. Madley concludes: "examining the intentions and actions of colonizers and their advocates it is possible to reinterpret some of these cataclysms as both genocides and wars of resistance" (120). In a history that has not attracted many researchers, Madley finds that settlers who traveled across the Applegate Trail to the California gold fields brought with them livestock and hunted wild game to exhaustion. This disrupted the delicate ecosystem the Modocs had cultivated for hundreds of years. As Modocs resisted the invasion, the Governor of California, Pete Burnett, called for "a war of extermination ... to be waged ... until the Indian race becomes extinct" (96). This quote is evidence that the state intended to eliminate an ethnic group. Whaley's short essay reinforces these findings. His analysis focuses on southern Oregon, but many of the names are familiar. Like California, settlers in the Willamette and Rogue River valleys articulated a policy of elimination and secured the blessings of the state to carry it out. They did so under a guise of "folk imperialism," a concept Whaley introduces to chronicle what happens when settlers "wield democratic values against those defined as outside the protection of [natural] rights" (143). Simply put, settlers rallied around the populist ideology of white supremacy to the great detriment of Native Americans.

Kiera Ladner and Colin Samson also explore genocide in Canada. Passed in 1876, Saskatchewan's Indian Act has remained largely unchanged and continues to undermine Indigenous sovereignty. This, posits Ladner, constitutes political genocide. Samson's essay analyzes the Innu Nation Land Claim in northern and eastern Canada. He reminds us that while land claims and settlement acts are usually viewed as an even-handed way to resolve disputes, these acts are undertaken and created by settler states and backed by coercion. The Innu from Labrador exerted claims over land to prevent industrial development and environmental spoliation, but they were ultimately unsuccessful in maintaining their subsistence ways of life. Rather, the Innu were incorporated into a capitalist system that pursued relentless expansion as they were forced to adapt.

The final essays of the volume include those by Joseph P. Gone, Tasha Hubbard, David B. MacDonald, and an afterword by Alexander Laban Hinton. Gone defines genocide as "group-based mass murder" and thus not always an accurate way to express settler/Indigenous relations (275). Gone concurs that genocide occurred in some contexts but suggests that the central aim of the United States was the acquisition of property. Thus the settler nation dispossessed Indigenous people of land at a greater rate than it exterminated them outright. Hubbard's 
imaginative contribution considers a less human-centric notion of colonization and genocide, one that incorporates the fate of the buffalo on the Plains into the broader history of Indigenous people. By this measure, the purposeful slaughter of the American Bison by white settlers met the standards of genocide per the UN definition.

Colonial Genocide in Indigenous North America is the published culmination of a conference on the topic. As such, the collection is at times uneven, and the contributors are rooted in a variety of disciplines. These disparate scholarly backgrounds place the reader off kilter and searching for some methodological cohesion to the essays. Furthermore, it is not always clear how the essays relate to the respective themes the editors established from outset. For example, there are five essays that discuss Canadian Residential Schools; yet they are spread across separate sections of the collection and sometimes talk past one another. Beyond the organizational weaknesses of the volume, the title suggests an explicit emphasis on colonial genocide in North America; but discussion of Mexico or the North American borderlands is conspicuously absent. Finally, the authors seem to walk a fine line. On the one hand, they agree that genocide is an accurate and necessary way to interpret the interaction between Indigenous and European peoples in several contexts. On the other hand, the authors all take great pains to avoid reducing the entirety of North American colonization to an act of genocide. Doing so runs the risk of derailing meaningful discussions of Indigenous resistance, cultural persistence, and creative adaptation. These concepts, while not packing the rhetorical punch that the term "genocide" does, remain every bit as central to Indigenous experiences in North America.

Like Colonial Genocide, Laura R. Graham and H. Glenn Penny have edited their collection from the proceedings of a conference. While Colonial Genocide in Indigenous North America takes mass violence as a common theme, Performing Indigeneity: Global Histories and Contemporary Experiences "highlights the ways in which cultural performances directed at new audiences can lead to cultural revitalization within Indigenous communities" (11). The contributors demonstrate how performance and culture at once facilitate resistance as well as offer a space to transcend European prerogatives.

Several of these essays deserve commentary, and of the three volumes reviewed here, this one is by far the most global in scope. Dorothy Hodgson's essay explores how the Maasai of Kenya and Tanzania deployed culture and performance, sometimes borrowing from other groups, to bolster their claim to indigeneity before the United Nations. The UN has become a key ally for many Maasai who have seen their land claims stripped by the Kenyan and Tanzanian governments. Hodgson claims, "only at the UN are Indigenous activists now welcome to directly address state representatives, donors, UN officers, and each other in a regular, internationally recognized, state-sanctioned forum" (75). Michael L. Cepek's topic is the Cofán people of Amazonian Ecuador and their unlikely representative, Randy Borman, "a man whose blue eyes, pale skin, and flawless English point directly to his Euro-American descent" (83). Cepek proposes that 
Borman's accepted status as a full member and leader of the Cofán complicates notions of membership and showcases the fluidity of race and identity in twentyfirst century settler societies.

Catherine Baglo positions the Sami of northern Norway, Sweden, Finland, and Russia in relation to Indigenous people in the North American West. She challenges the "trope of victimization" by demonstrating how Sami exhibitions, like Buffalo Bill Cody's famous Wild West shows, provided Indigenous people a venue to showcase their traditions despite their seemingly exploitative function. H. Glenn Penny summarizes some of the findings from his book, Kindred by Choice, as he relates the unlikely fascination that German hobbyists have long displayed towards North America's Indigenous population. ${ }^{4}$ Penny traces this back to the popularity of James Fennimore Cooper's Leatherstocking Tales (translated into German in 1826). To Penny, Germans felt akin to North American Indians and viewed themselves as indigenous to Europe. As Germanic people once resisted the Roman Empire, the Plains Indians resisted the encroachment of white settlers. Though the analogy is stretched, it has woven its way into contemporary German culture. Penny has labeled Germany's ingrained fascination with Native Americans, "surrogate Indigeneity" (175). But rather than dismiss this peculiar phenomenon as cultural appropriation, Penny proposes that we might take away valuable insights into how Germans have constituted their own self-identity and how they perceive themselves within the broader European community.

Other essays scrutinize indigeneity in the Pacific. Ty P. Kawika Tengan argues gender is a key site of colonial contestation in Hawai' $i$. Gender identity and expression may reinforce settler dominance on the one hand, or it might serve as a mode of resistance on the other hand. Tengen claims that native masculinity has been elided by colonial discourses in Hawai'i. Instead, notions of settler manliness exemplified by "Uncle Sam" and American GIs, or Indigenous femininity embodied by the stereotypical "hula girl," has prevailed and informed white perceptions of the islands (211). Brendan Hokowhitu and Fred Myers examine the appropriation of Indigenous culture in New Zealand and Australia, respectively. This is apparent through the deployment of a Maori Haka dance known as the $\mathrm{Ka}$ Mate at the beginning of rugby matches featuring New Zealand's national team, the All Blacks. Hokowhitu suggests that the use of Haka and "traditional" performances of Maori masculinity, rooted in an exoticized depiction of warrior culture, commodifies indigeneity and has led the team to secure lucrative marketing deals with multinational corporations such as Adidas. Myers considers how Aboriginal acrylic painters in Australia complicate our conception of performative indigeneity as a "problematic or contradictory act — crossing, intersecting, and perhaps challenging social, political, and/or cultural boundaries and regimes of value" (352). Art has long functioned as a means by which Aboriginal people have portrayed the land and propagated their history. As such, artwork is not simply a commodity to market and sell; it reveals Indigenous folkways that have developed independently from European influence. 
The Penny and Graham volume leans more heavily on ethnographic approaches than do the other two books reviewed. Colonial Genocide in North America and An Indigenous Peoples' History of the United States are written with a decidedly activist bent and will likely resonate with historians more than others. Meanwhile, Performing Indigeneity is more global in its scope and content, and it is more theoretically informed. But the three books demonstrate a rich array of methodological approaches and effectively present Indigenous points of view. Finally, these studies arrive at a particularly timely moment. Canada's Truth and Reconciliation Commission (TRC) held its closing events in June 2015. The TRC concluded that the residential schools carried out "cultural genocide." 5 While it remains unclear what impact the commission's findings will have on future public policy, it nevertheless marks a turning point between Canada's federal government and the First Nations. The TRC may also spark debate on the legacy of colonialism and a serious discussion of how its processes continue to shape our present as much as they have defined our past. At the time of writing this review, however, there is little reason to believe political leadership in the United States, among other settler nations, might call for a similar commission. Yet, scholars and activists on the ground are advancing new knowledge, conducting research, and engaging questions of citizenship, sovereignty, violence, history, and resistance with great incisiveness and bold clarity. As a result, these books should be required reading for anyone who wishes to thoughtfully and constructively engage the topic of colonialism and what it has wrought.

\section{Notes}

1. Jodi Byrd, The Transit of Empire: Indigenous Critiques of Colonialism (Minneapolis: University of Minnesota Press, 2011), xii.

2. The definition of "genocide" largely agreed upon by scholars and activists emerged from the 1947-48 United Nations Convention on the Prevention and Punishment of the Crime of Genocide. See the influential Rapheal Lemkin, Axis Rule in Occupied Europe: Laws of Occupation, Analysis of Government, Proposals for Redress (Washington DC: Carnegie Endowment for International Peace, Division of International Law, 1944), which provided much of the language for the United Nations resolution.

3. On this point, Dunbar-Ortiz echoes a slew of other historians. For a recent work, see Colin G. Calloway, The Scratch of Pen: 1763 and the Transformation of North America (New York, NY: Oxford University Press, 2007).

4. See H. Glenn Penny, Kindred by Choice: Germans and American Indians since 1800 (Chapel Hill: University of North Carolina Press, 2013).

5. For a detailed summary of the TRC findings, see Truth and Reconciliation Committee of Canada, "Honouring the Truth, Reconciling for the Future: Summary of the Final Report of the Truth and Reconciliation Committee of Canada." http://www.trc.ca/websites/trcinstitution/File/2015/ Findings/Exec_Summary_2015_05_31_web_o.pdf (Accessed on June 17, 2015). 
